The Writers 



\section{The Writers}

\section{A History of American Screenwriters and Their Guild}

MIRANDA J. BANKS

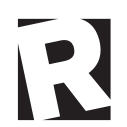

RUTGERS UNIVERSITY PRESS 


\section{LIBRARY OF CONGRESS CATALOGING-IN-PUBLICATION DATA}

Banks, Miranda J., 1972-

The writers : a history of American screenwriters and their Guild / Miranda J. Banks.

pages $\mathrm{cm}$

Includes bibliographical references and index.

ISBN 978-O-8I35-7I39-3 (hardcover : alk. paper) - ISBN 978-0-8I35-7I38-6

(pbk. : alk. paper) - ISBN 978-O-8I35-7I4O-9 (e-book)

I. Motion picture authorship-United States-History. 2. Writers Guild of America-History. 3. Motion picture industry-Employees-Labor unions-United States. 4. Television broadcasting-Employees-Labor

unions-United States. 5. Screenwriters-United States-Interviews.

I. Title.

PNi996.B382 2015

812'.0309-dc23

$20140 I 4280$

A British Cataloging-in-Publication record for this book is available from the British Library.

Material used in chapter 5 was originally published in a much abbreviated form in "The Picket Line Online: Creative Labor, Digital Activism, and the 2007-2008 Writers Guild of America Strike," in Popular Communication 8 (2010): 20-33. Small portions of the Introduction were published in "Oral History and Media Industries," in Cultural Studies 8 no. 4 (20I4).

Copyright @ 2015 by Miranda J. Banks

All rights reserved

No part of this book may be reproduced or utilized in any form or by any means, electronic or mechanical, or by any information storage and retrieval system, without written permission from the publisher. Please contact Rutgers University Press, I06 Somerset Street, New Brunswick, NJ 089oI. The only exception to this prohibition is "fair use" as defined by U.S. copyright law.

Visit our website: http://rutgerspress.rutgers.edu Visit the author's website: http://www.mirandabanks.tv Manufactured in the United States of America 